\title{
THE INFLUENCE OF LOCAL FOOD BRAND IMAGE ON CONSUMER PURCHASE DECISION DURING COVID-19 PANDEMIC
}

\author{
Erny Hutabarat ${ }^{1}$, Agus Pahala Tua ${ }^{2}$ \\ President University \\ Email: ernyhutabarat@president.ac.id ${ }^{1}$, aguspahalatua@gmail.com² \\ Received: October $5^{\text {th }} 2021$ \\ Approved: November $4^{\text {th }} 2021$
}

\begin{abstract}
The Covid-19 pandemic that occurred at the end of 2019 has caused an economic downturn in Indonesia and the government has also appealed to the public to immediately implement health protocols. As a result, many franchisees experienced a decline in revenue, including national and international franchises. The purpose of this study is to analyze the purchasing decisions of the community at the local franchise Martabak Roland in South Tambun, Bekasi, West Java. This local franchise brand image has a very good image, purchase intention is used in this study as an intervening variable. This research is a quantitative study using an online questionnaire as a data collection tool, with a sample of 100 respondents. Hypothesis testing uses the Structural Equation Model (SEM). The results showed that brand image and price had no significant effect on purchase intentions and food quality had no effect on purchase intentions. Meanwhile, the Purchase intention variable which is classified as moderate has a significant effect on the decision to purchase a local franchise during Covid19.
\end{abstract}

Keywords: Covid-19, Purchase Decision, Brand Image, Purchase Intention, Food Quality

\section{Introduction}

An interesting phenomenon in recent years is growing rapidly, Food Franchising Business. If we observe that there are currently many very creative new businesses offering various kinds of products and services, for example the modern food business. Some of them open outlets in shopping centers or on main roads with strategic locations in the city center (Slamet, 2011). In Indonesia, this form of business is growing too rapidly, this form is used by local business actors in Indonesia (Astuti, 2005).

Martabak is a fairly popular food processed the people of Tambun Selatan District, this is because of the good taste of Martabak available with various flavors and affordable martabak prices all walks of life. The times and the increasing desire of people for capable culinary 


\section{Journal of Management and Leadership}

Vol.4 No.1, May 2021

satisfying their cravings, but also contemporary and popular culinary delights to increase status social and class, that is what makes the appearance of a sweet martabak even more modern and attractive. If all this time the sweet martabak only contains chocolate toping, cheese, nuts, and various jams which are then folded and cut into squares, now a sweet martabak appears different (Veronika, 2018).

Roland's Martabak Franchise is one of the fields that has a strong brand image in the minds of the people of South Tambun. This is because this franchise has long been established in the area and besides that it is the only one that has a taste that varies from other franchises, with its special menu. Even if we are asked about the brand's martabak, what consumers think of for the first time is because the Roland brand is already attached to the consumer's memory. Brand image can be considered as a type of associations that come to the minds of consumers when remembering a particular brand, the association can simply be appears in the form of thoughts or images certain that is attributed to a brand, it's the same when thinking about other people (Shimp, 2003).

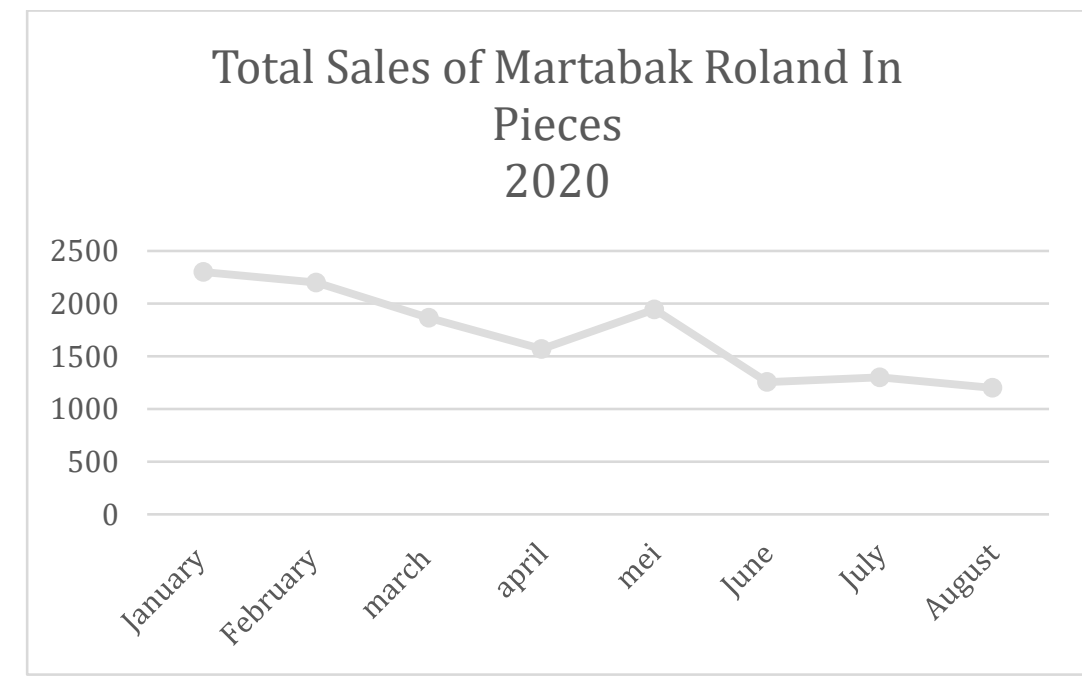

Figure 1 Total Sales in pieces of Martabak Roland Outlets, Mangun Jaya

Martabak Roland has 4 branches spread across Bekasi Regency. In the midst of this pandemic, the franchise experienced a significant decline in turnover from January to August 2020, each month experiencing a decline in sales as seen in the figure above. Through an interview at one of the branches on Jl. Education in Mangun Jaya Tambun Selatan Regency is known that the number of sellers has decreased quite significantly, as seen in Figure 1 which indicates a decrease in sales, the most significant is seen in June and August 2020. 


\section{Journal of Management and Leadership}

Vol.4 No.1, May 2021

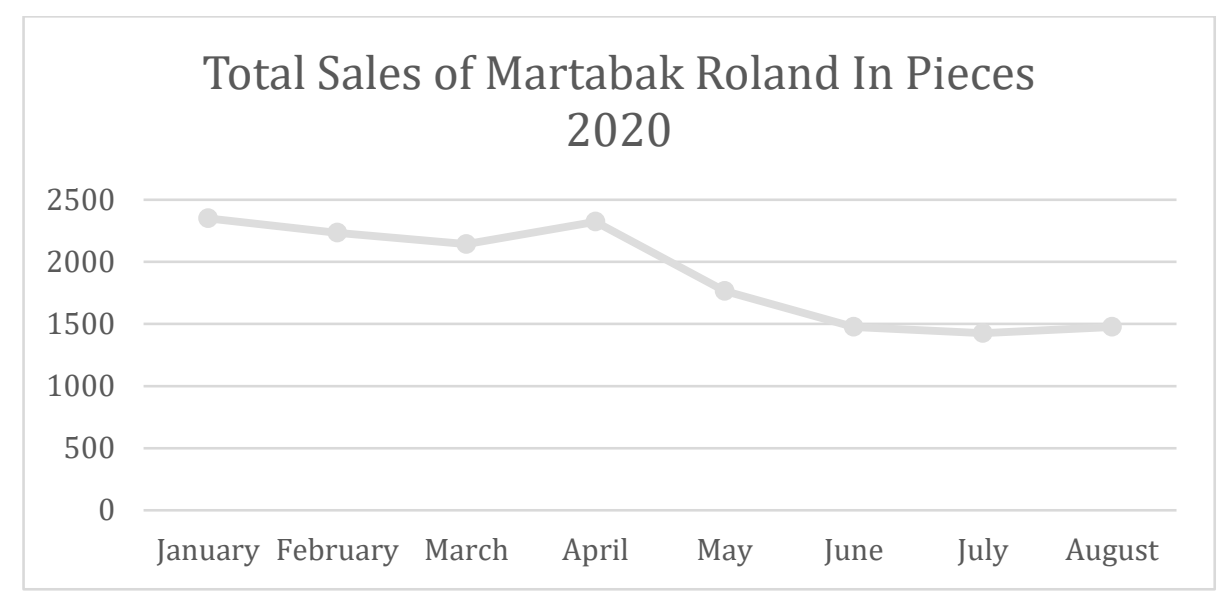

Figure 2. Total Sales of Martabak Roland Outlets Wanasar

Figure 2 shows that sales at one of Roland Martabak's branches on Jl. Bosih Raya Selang Tengah Wanasari Cibitung Bekasi District has experienced a decline, Rahmad as the owner said that the decline in sales was most likely due to the COVID-19 pandemic, thus reducing people's purchasing power. The crisis due to the Covid-19 pandemic has had a huge impact on many business actors. Including business actors in the franchise sector. Until now, the franchise business growth in Indonesia is considered quite good and developing. During this pandemic, a number of franchise businesses have also taken a hit. franchise network players must really think about the right strategy in terms of operational management and branding. In matters of operational management, apart from maintaining cash flow, they must regulate the rhythm of their business (Susanty, 2020).

COVID-19 is a disease infectious caused by syndromes Acute respiratory coronavirus 2 (severe Acute respiratory syndrome coronavirus 2 or SARS-CoV-2). This virus is the large Coronavirus family that can attacking animals. When it strikes humans, usually the Corona virus cause tract infection disease inhalation, such as flu, MERS (Middle East Respiratory Syndrome), and SARS (Severe Acute Respiratory Syndrome). COVID-19 itself is a new type of corona virus which was found in Wuhan, Hubei, China in 2019 (Ilmiyah et al, 2020).

Until Saturday 28, March 2020 as many as 3 patients in Bekasi district had recovered. Based on information from the official website of the Bekasi District Health Office on Saturday at 20:40 WIB, a total of 20 positive cases of Covid-19 in Bekasi Regency. Of these, 13 patients were treated, three patients recovered, and four died. The number of patients under surveillance (PDP) in Bekasi District, namely 104 people and residents with the status of people under monitoring (ODP) totaled 382 people. Meanwhile, information data on Saturday at $08.00 \mathrm{WIB}$, the highest number of positive Covid-19 patients in Bekasi Regency was in 


\section{Journal of Management and Leadership}

Vol.4 No.1, May 2021

South Tambun District, namely 15 patients. Tambun Selatan Subdistrict is also the region with the highest number of PDP, namely 27 people and ODP 96 people (Pahrevi, 2020).

In a difficult situation as a result of the Covid-19 pandemic disaster, franchise businesses need to take strategic steps. This policy certainly has to be the concern and anticipation of business actors in Indonesia. The Covid-19 disaster had an impact on the business world, including the franchise business. The Covid-19 pandemic has an impact on various aspects of life, including the franchise business sector. In various $\mathrm{s}$ discussions with franchise, licensing and partnership businesses in Indonesia, the turnover of franchisees has dropped by 50\%, some have even closed their outlets to address the safety of employees and customers in order to implement social distancing (Investor.id, 2020).

\section{Literature Review}

In research conducted by Chandra \& Santoso shows that brand image is influential significant in purchasing decision, Product quality has a significant effect on purchasing decision, price has a significant effect, Product quality and price significant towards the purchase decision at the mini Melts outlet Surabaya.

In research conducted by Berga \& Sari showed that product quality, the price, and word of mouth significant on the process decision the purchase.

Based on statistical data analysis, the indicators of this study are valid and the variables are reliable. Food quality and brand image have an influence on purchasing decisions. Hypothesis testing using the $\mathrm{T}$ Test shows that food quality variables and brand image have been shown to significantly influence the dependent variable of purchasing decisions (Fiani \& Japarianto, 2012).

\section{Research Question}

1. Does Brand Image Influence Purchasing Decisions of Roland Martabak franchise customers during the Covid 19 pandemic through purchase intention as a Variable intervention?

2. Does Price Influence Purchasing Decisions of Roland Martabak franchise customers during the Covid 19 pandemic through purchase intention as a Variable intervention? 


\section{Journal of Management and Leadership}

Vol.4 No.1, May 2021

3. Does Food Quality Influence Purchasing Decisions of Roland Martabak franchise customers during the Covid 19 pandemic through purchase intention as a Variable intervention?

4. Does Purchase Intention Influence Purchasing Decisions of Roland Martabak franchise customers during the Covid 19 pandemic through purchase intention as a Variable intervention?

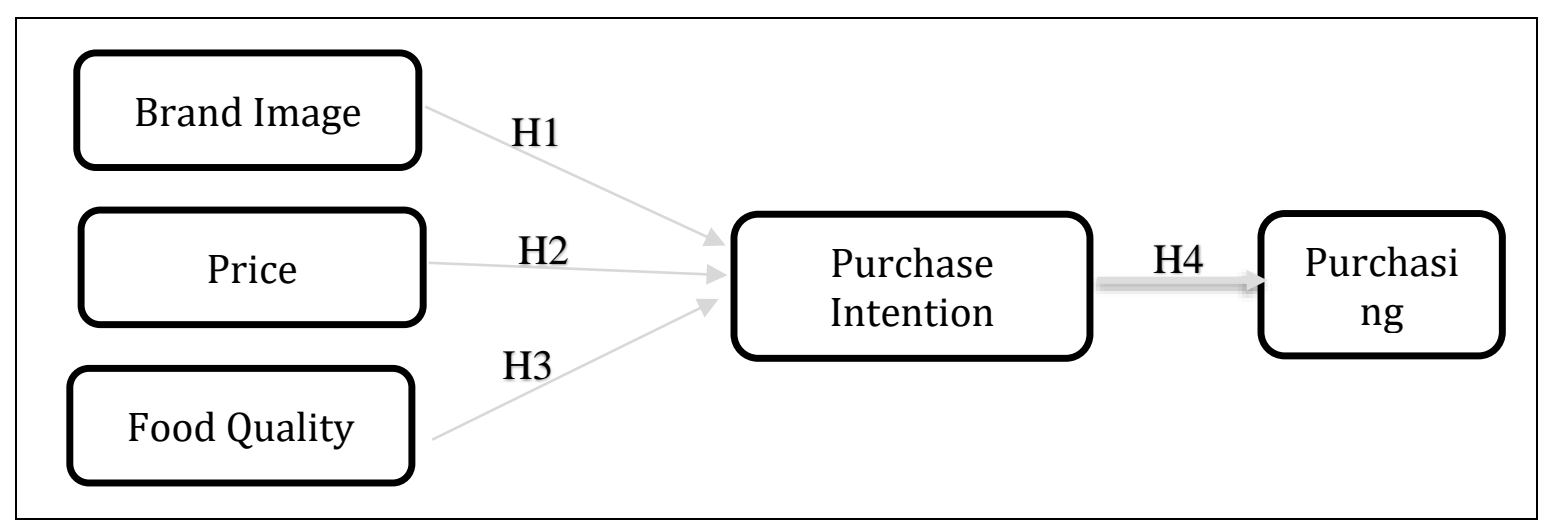

Figure 3. Theoretical Framework

\section{Methodology}

The design of the research is the conceptual context within which the research is carried out; it constitutes a model for data collection, calculation and analysis. As such the design provides a diagram of what the researcher would do from writing the hypothesis and its operational consequences to the final data review. Therefor the research design can be described as a research plan, structure and strategy to find alternative methods to solve the problems and minimize the variances (Kothari, 2004).

According to Creswell (2010) the study will be pre-determined in this quantitative method, statistical data analysis and statistical data interpretation. Researchers using a quantitative approach will test a theory by specifying a specific hypothesis, then collect data to support or refute those assumptions. The method to be taken in this study is a quantitative, statistical knowledge base method to analysis. A research approach that responds to research problems requires careful measurement of the variables of the object being studied in order to produce conclusions that can be generalized regardless of the time, location and situation.

Quantitative approaches may be defined as approaches of study, based on positivism theory. This approach is used to investigate a particular population or sample, to collect data using 


\section{Journal of Management and Leadership}

Vol.4 No.1, May 2021

analysis instruments, to analyze quantitative/statistical data, in order to test a predetermined hypothesis. (Sugiono, 2012).

For each study the data may be collected through two methods, namely census (in which all units of a population are studied) and sample (in which a portion of a population is studied). Typically, the most effective method of gathering data is by using a sampling strategy, the form of universe, sampling unit, sampling frame, sample size and sampling techniques. The sample size applies to selected population units which should be neither too large nor too small and should be optimal in general. The sample size depends on certain variables such as population size, population character, kind of analysis. The technique of sampling is divided into two techniques called probability and non-probability. The probability sampling techniques are techniques that give every unit of the universe equal opportunity to be a sample member. The non-probability sampling method "also known by different names, such as intentional sampling, purposeful sampling and sampling of decisions. In this method of sampling, items for the survey are purposely selected by the researcher; his preference as to the items remains supreme (Kothari, 2004).

In this study we will use probability sampling with random sampling techniques. A simple random sampling technique is a sampling technique carried out randomly by members of the population without regard to the strata in that population (Sugiono, 2013).

According to Sugiono (2013) population is a field of generalization containing objects / subjects with certain characteristics and attributes. Determined to be investigated by researchers and then conclusions drawn. The population of this study is unknown Population, who will be the consumers who bought Martabak Roland franchise during the pandemic covid-19.

The sample is a portion of the population's number and features (Sugiono, 2013). According to Sugiyono (2016) defines the sample is as follows: "Samples are part of the number and characteristics possessed by the population. Sample measurement is a step to determine the size of the sample taken in carrying out research of an object. To determine the sample size can be done statistically or based on research estimates. This sampling must be carried out in such a way as to obtain a sample that can truly function or can describe the actual state of the population, in other words it must be representative. The number used in this study amounted to 100 respondents, this is based on Sugiyanto's (2011) opinion that the appropriate sample size in this study is between 30 to 500. Then the determination of the number of 100 
respondents has entered the criteria so it is worthy of research. "The sample of this study is about 100 random people who will be consumers during the pandemic covid-19”.

\section{Result}

This study analyzes the effect of purchase intention and purchase decisions on food quality, price and brand image. Is an independent variable, where purchase intention is a moderating variable, and purchasing decision is the dependent variable This research produces several interpretations.

For the convergent validity test, each indicator's load factor must exceed 0.6, while the average variance extracted (AVE) score must exceed 0.5 .

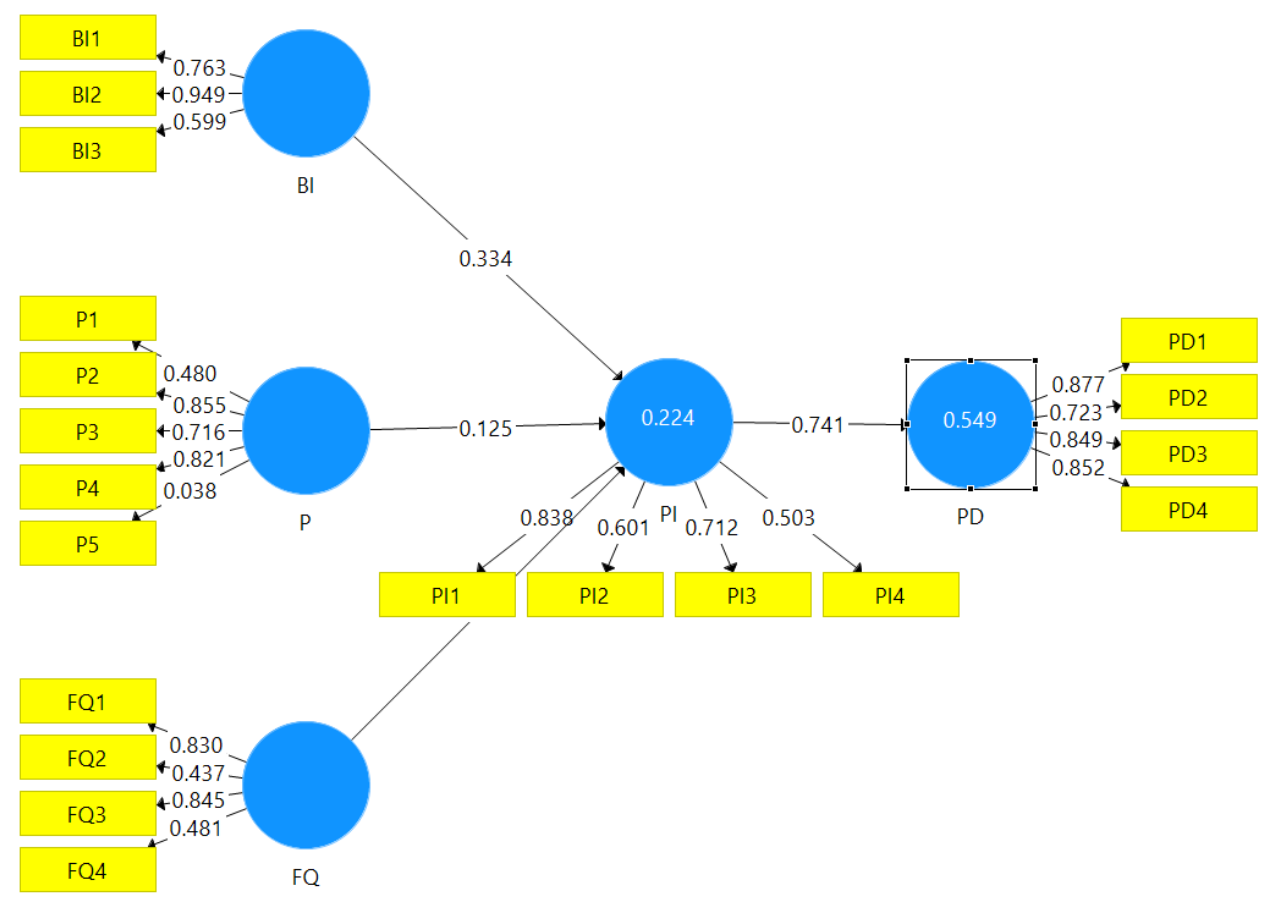

Figure 4. Pre-test loading factor

The pretest results show that there 5 invalid constructs out of the 20 constructs because the outer loading value is lower than 0.6, namely BI3, P1, P5, FQ2, FQ4, PI4 has to be removed to obtain better performance. In the table below you can see the effects of the convergent validity. 


\section{Journal of Management and Leadership}

Vol.4 No.1, May 2021

Table 1. Pre-Test AVE score

\begin{tabular}{|c|c|}
\hline & Average Variance Extracted \\
\hline Brand Image & 0.781 \\
\hline Food Quality & 0.802 \\
\hline Price & 0.649 \\
\hline Purchase intention & 0.686 \\
\hline Purchasing Decision & 0.560 \\
\hline
\end{tabular}

After removing invalid construct, the data shows that at least all variable have an AVE value above 0.5 . even though the purchase intention and brand image variable are almost at 0.5

reliability analysis was carried out using Cronbach's Alpha and the composite reliability test. Test results can be seen in the table below to ensure the Cronbach alpha test is correct. It has been stated that the results of Cronbach's alpha have a minimum score of 0.5 , and the results shown in the table indicate that all variants have a score higher than 0.5 , and this analysis meets criteria for reliability. Looking at the value of composite reliability, it can be shown that all of them in the table below have a value of 0.6 and above and it can be inferred that all of the metrics are essentially a measure of perspective building.

Table 2. Cronbach's Alpha

\begin{tabular}{|c|c|c|c|}
\hline & Cronbach's Alpha & Rho_A & $\begin{array}{c}\text { Composite } \\
\text { Reliability }\end{array}$ \\
\hline Brand Image & 0.689 & 0.700 & 0.869 \\
\hline Price & 0.672 & 0.684 & 0.858 \\
\hline Food Quality & 0.717 & 0.720 & 0.842 \\
\hline Purchase Intention & 0.812 & 0.813 & 0.889 \\
\hline Purchase Decision & 0.910 & 0.930 & 0.936 \\
\hline
\end{tabular}

Based on the data above, seen from the value of Cronbach's Alpha and Composite Reliability, it can be ascertained that this research is valid and declared reliable. 


\section{Journal of Management and Leadership}

Vol.4 No.1, May 2021

Path analysis is a method developed to examine the direct and indirect relationship of several variables, where some variables are seen as explanatory variables from other variables which are seen as response variables. Path analysis is intended to combine quantitative information from the results of the correlation analysis with qualitative information as a causal relationship that may have existed before to provide a quantitative interpretation.

Table 3. Table Path Coefficient

\begin{tabular}{|c|c|c|c|c|c|c|}
\hline & $\begin{array}{l}\text { Original } \\
\text { Sample }\end{array}$ & $\begin{array}{l}\text { Sample } \\
\text { Mean }\end{array}$ & $\begin{array}{l}\text { Standard } \\
\text { Deviation }\end{array}$ & $\begin{array}{c}\mathrm{T} \\
\text { Statistic }(|\mathrm{O} / \mathrm{STDV}|)\end{array}$ & $\begin{array}{c}\mathrm{P} \\
\text { values }\end{array}$ & Description \\
\hline $\begin{array}{c}\text { Brand } \\
\text { Image - } \\
>\text { Purhcase } \\
\text { Intention }\end{array}$ & -0.102 & -0.086 & 0.129 & 0.794 & 0.427 & $\begin{array}{c}\text { Not } \\
\text { significant }\end{array}$ \\
\hline $\begin{array}{c}\text { Price }> \\
\text { Purchase } \\
\text { Intention }\end{array}$ & 0.225 & 0.569 & 0.134 & 1.681 & 0.093 & $\begin{array}{c}\text { Not } \\
\text { significant }\end{array}$ \\
\hline $\begin{array}{c}\text { Food } \\
\text { Quality> } \\
\text { Purchase } \\
\text { Intention }\end{array}$ & 0.545 & 0.540 & 0.126 & 4.337 & 0.000 & Significant \\
\hline $\begin{array}{c}\text { Purchase } \\
\text { Intention> } \\
\text { Purchase } \\
\text { Decision }\end{array}$ & 0.560 & 0.540 & 0.095 & 5.870 & 0.000 & Significant \\
\hline
\end{tabular}

At this stage, to determine whether or not a dependent variable has a significant effect on the independent variable, it can be seen in the Path Coefficients table after bootstrapping. Look at the value of T-statistics if $>1.96$ then it has a significant relationship.

This study analyzes the effect of purchase intention and purchase decisions on food quality, price and brand image. Is an independent variable, where purchase intention is a moderating 


\section{Journal of Management and Leadership}

Vol.4 No.1, May 2021

variable, and purchasing decision is the dependent variable. This research produces several interpretations.

Brand Image Variables effect to Purchase intention on the Martabak Roland Franchises. In the first hypothesis, the result shows that brand image has no significant effect has an effect on purchase intention. This can be seen from the T-statistic whose value is less than 1.96 that is 0.794. the results of this study were different from An-Tien Hsieh \& Chung-Kai Li (2007) but the results of this study are supported by previous research (Fiani et.all, 2012) which states that brand image has no significant effect on purchase intention.

Price Variables effect to Purchasing intention on the Martabak Roland Franchises. For the second hypothesis, the findings indicate that there is a correlation between price and Purchase intention. The T-statistic value reached 1,681 smaller than the norm, namely 1.96, and also has a $\mathrm{P}$ value of 0.093 , It can be seen in the table. Which shows that the price variable does not have a significant effect on purchase intention. This result is also supported by (Halim \& Iskandar, 2019) which proves that price has no effect purchase intention. but the results of this study were different from previous research Apriyani (2012).

Food Quality Variables effect to Purchase intention on the Martabak Roland Franchises.The third hypothesis shows that Food quality have significant effect on purchase intention. This can be seen from the T-statistic whose value is more than 1.96 which is 4.334 . This result is also supported based on another article (Fiani \& Japarianto, 2012).

Purchase Intention Variables effect to Purchasing decision on the Martabak Roland Franchises.

The last hypothesis also has a significant result, it shows that the purchase intention has a significant influence on purchasing decision. As in the results, the T-statistic gets a value of 5.870 which is greater than 1.96 and has a value of 0.000 as the $\mathrm{P}$ value. This result is also supported by the previous research (Febriyanti \& Wahyuati, 2016) which states that the Purchase Intention has a significant influence on Purchasing decision.

\section{Conclusions and Recommendations}

The conclusions Based on the result of hypothesis testing and discussion the result show that Brand image have no significant effect on consumer Purchase Intention of the Roland franchise martabak franchise during the Covid 19 pandemic which is mediated by the 


\section{Journal of Management and Leadership}

Vol.4 No.1, May 2021

purchase interest variable. Food Quaility and Purchase intention affects consumer purchasing decisions of the Roland franchise martabak franchise during the Covid 19 pandemic which is mediated by the purchase interest variable.

Recommendation for Franchisor, namely as follows:

1. The Covid-19 pandemic spreading around the world, especially for local food franchises, must have higher product quality of food to meet the standards of Purchase interest from customers.

2.Everyone has a different perception of price and quality standard, therefore local franchise food entrepreneurs must provide a level of quality and price that is acceptable to the majority of the community in order to increase buyer interest in local franchises amid the conditions of the Covid 19 pandemic.

\section{References}

Astuti, D. (2005). Kajian bisnis franchise makanan di Indonesia. Jurnal manajemen dan kewirausahaan.

Farida, L. (2020). Dampak Corona terhadap Industry Food and Beverage dan Solusi yang ditawarkan agar Bisnis tetap berjalan (Impact of Corona Toward Industry Food and Beverage and Solution That Offered So The Business Keep It Running).

Fiani. 2012. Analisa Pengaruh Food Quality dan Brand Image terhadap Keputusan Pembelian Roti Kecik Toko Roti Ganeps di Kota Solo. Jurnal Manajemen Pemasaran. Vol. 1. No. 1.

Fiani, M., \& Japarianto, E. (2012). Analisa pengaruh Food quality dan Brand image terhadap keputusan pembelian roti kecik. Jurnal Manajemen Pemasaran.

Hopkins SEE. (2020, 6 August). COVID-19 Map - Johns Hopkins Coronavirus Resource Center. Accessed 6 August 2020, from https://coronavirus.jhu.edu/map.html

Hutabarat, E., \& Suweta, E. (2020). Experential Marketing And Service Quality on WOM Reccomendation Through Satisfaction as mediation variable of rudana museum, Bali. ICFBE 2020.

Investor.id. (2020, 29 March). Mengelola Bisnis Waralaba Saat Pandemi. Accessed on 6 August 2020, from https://investor.id/opinion/mengelola-bisnis-waralaba-saatpandemi

Kerlinger, Fred N. \& Howard B. Lee. 2000. Foundations of Behavioral Research. 4 th Edition. Florida: Harcourt Inc.

Kothari,C.R. 2004. Research Methodology:Methods and Techniques. New Delhi: New Age International (P) Ltd.,Publishers.

Kotler, P., \& Keller, K. L. (2007). Manajemen Pemasaran. Jilid I, Edisi 12. Jakarta: PT. Indeks Kelompok Gramedia

Kotler dan Gary Armstrong (2012). Principles of Marketing Global Edition, 14 th Edition, Pearson Education.

Kotler dan Keller. (2009). Manajemen Pemasaran. Jilid I Edisi 13. Jakarta: Erlangga. 
Liewin, S. L., \& Genoveva. (2020). The role of Purchase intention on international of food Brands during COVID-19 PANDEMIC. ICFBE.

Meilani, Y. F. C. P., \& Simanjuntak, S. (2012). Faktor yang mempengaruhi minat beli produk makanan dan minuman usaha kecil menengah kabupaten Tangerang. Jurnal Manajemen dan Kewirausahaan.

Moka. (2020). Industri Food \& Beverage Terkena Dampak Paling Signifikan Akibat Virus Corona, sedang Pendapatan Harian Industri Ritel Terjun Bebas. Retrieved APRIL 7, 2020, from Moka Pos :https://blog.mokapos.com/industri-fb-terkenadampak-palingsignifikan-akibat-virus-corona.

Philip, Kotler dan Amstrong. 2012. Prinsip-Prinsip Pemasaran. Jakarta: Erlangga.

Saladin, D. 2008. Manajemen Pemasaran Analisis, Perencanaan, Pelaksanaan, dan Pengendalian. Bandung: Linda Karya.

Santoso. 2016. Peran Kualitas Produk dan Layanan, Harga dan Atmosfer Rumah Makan Cepat Saji terhadap Keputusan Pembelian dan Kepuasan Konsumen. Jurnal Manajemen Teknologi. Vol. 15. No. 1.

Schiffman, Leon, L. L. K. (2012). Perilaku Konsumen. Jakarta: PT.INDEKS.Sekaran, Uma. 2006. Metodologi Penelitian Untuk Bisnis. Edisi IV. Jakarta: PT.

Shimp, A., (2003), "Periklanan Promosi Aspek Tambahan Komunikasi Terpadu", Jakarta: Erlangga. Salemba Empat.

Slamet, S. R. (2011). Waralaba (Franchise) di Indonesia. Lex Jurnalica.

Sitinjak, Tumpal JR dan Sugiarto. (2006). LISREL. Yogyakarta: GRAHA ILMU.

Sugiyono. (2011). Metode Penelitian Kuantitatif Kualitatif dan R\&D. Bandung: CV. Alfa Beta.

Sugiyono, Metode Penelitian Kuantitatif, Kualitatif, dan R \& D, (Bandung: Alfabeta, 2009).

Sugiyono. (2013). Metode Penelitian Pendidikan. Bandung: Alfabeta

Suharnoko, "Hukum Perjanjian : Teori dan Analisa Kasus", Cet. 1, Kencana, Jakarta, 2004.

Sumarwan, Ujang. 2004. Perilaku Konsumen (Teori dan Penerapannya dalam Pemasaran). Bogor: Penerbit Ghalia Indonesia.

Veronica, E., Burhanudin, A. Y., \& Aryati, I. (2018). Pengaruh Brand image, Harga, Dan Produk terhadap Loyalotas pelanggan martabak Brengos (DMRONGOS) SOLO. Jurnal Manajemen dan Keuangan. 